\title{
Microsatellite characterisation and sex-typing in two invasive parakeet species, the monk parakeet Myiopsitta monachus and ring-necked parakeet Psittacula krameri
}

\author{
Francesca S. E. Dawson Pell ${ }^{1}$ [ - Ben J. Hatchwell ${ }^{1} \cdot$ Alba Ortega-Segalerva $^{2} \cdot$ Deborah A. Dawson $^{1}$. \\ Gavin J. Horsburgh ${ }^{1}$. Juan Carlos Senar ${ }^{2}$
}

Received: 9 September 2019 / Accepted: 28 November 2019 / Published online: 11 December 2019

(c) The Author(s) 2019

\begin{abstract}
Invasive species can have wide-ranging negative impacts, and an understanding of the process and success of invasions can be vital to determine management strategies, mitigate impacts and predict range expansions of such species. Monk parakeets (Myiopsitta monachus) and ring-necked parakeets (Psittacula krameri) are both widespread invasive species, but there has been little research into the genetic and social structure of these two species despite the potential links with invasion success. The aim of this study was to isolate novel microsatellite loci from the monk parakeet and characterise them in both monk and ring-necked parakeets in order to facilitate future investigations into their behaviour and population ecology. Sex-typing markers were also tested in both species. Of the 20 microsatellite loci assessed in 24 unrelated monk parakeets, 16 successfully amplified and were polymorphic displaying between 2 and 14 alleles (mean $=8.06$ ). Expected heterozygosity ranged from 0.43 to 0.93 and observed heterozygosity ranged from 0.23 to 0.96 . Nine of the 20 loci also successfully amplified and were polymorphic in the ring-necked parakeet, displaying between 2 and 10 alleles. Suitable markers to sex both species and a Z-linked microsatellite locus were identified. A multiplex marker set was validated for monk parakeets. These novel microsatellite loci will facilitate fine and broad-scale population genetic analyses of these two widespread invasive species.
\end{abstract}

Keywords Population genetics $\cdot$ Microsatellite loci $\cdot$ Sex markers $\cdot$ Invasive species $\cdot$ Aves $\cdot$ Psittacidae

\begin{tabular}{ll}
\multicolumn{2}{l}{ Abbreviations } \\
PCR & Polymerase chain reaction \\
PIC & Polymorphic information content \\
$\mathrm{H}_{\mathrm{O}}$ & Observed heterozygosity \\
$\mathrm{H}_{\mathrm{E}}$ & Expected heterozygosity \\
$\mathrm{HWE}$ & Hardy-Weinberg equilibrium \\
$\mathrm{LD}$ & Linkage disequilibrium \\
EMBL-EBI & $\begin{array}{l}\text { European Molecular Biology Laboratory- } \\
\text { European Bioinformatics Institute }\end{array}$ \\
FDR & False discovery rate
\end{tabular}

Francesca S. E. Dawson Pell

fsedawsonpell1@sheffield.ac.uk

1 Department of Animal and Plant Sciences, University of Sheffield, Western Bank, Sheffield S10 2TN, UK

2 Museu de Ciències Naturals de Barcelona, $\mathrm{P}^{\mathrm{o}}$ Picasso $\mathrm{s} / \mathrm{n}$, 08003 Barcelona, Spain

\section{Introduction}

Invasive species are nonindigenous species that establish self-sustaining populations beyond their native range [1, 2]. The negative impacts of invasive species can be wideranging and include: extensive economic and environmental damage [3, 4], threats to biodiversity [5, 6] and damage to human health $[7,8]$. Two such invasive species are the monk parakeet (Myiopsitta monachus) and the ring-necked parakeet (Psittacula krameri).

As a popular pet species, tens of thousands of monk parakeets have been exported from their native South America to meet the demands of the international pet trade [9-11]. Subsequent breaches in captivity during transit or from holding areas, together with accidental or deliberate release by owners facilitated multiple invasion events across four additional continents (e.g. [9, 10]). In Europe, monk parakeets are now among the invasive bird species with the potential to cause the most acute economic impacts [3]. For example, substantial crop damage caused by foraging monk parakeets has been identified in the agricultural belt surrounding the 
city of Barcelona, Spain [12]; while in North America, their communal nests built on power lines and in electricity substations cause power outages and safety concerns [13].

Ring-necked parakeets, native to Asia and Africa [9], are the world's most widespread invasive parrot species, with populations reported in at least 35 different countries [e.g. $[14,15]$. Considered one of Europe's worst invasive species [3], ring-necked parakeets have wide-ranging negative impacts throughout their invasive range including outcompeting native cavity nesters for suitable nest-sites (e.g. nuthatches Sitta europea; [16]), killing native species through direct aggressive encounters (e.g. greater noctule bat Nyctalus lasiopterus; [17]), and causing severe economic damage [3].

Assessing the genetic structure of populations of invasive species can be key in understanding their origin and invasion history [18], investigating dispersal patterns [19], and determining eradication or management strategies [20]. Microsatellites are molecular markers that are regularly used in such studies, and polymorphic markers have already been published for both monk parakeets (12 markers) [21] and ring-necked parakeets (21 markers) [22]. Here we present the characterisation of novel polymorphic monk parakeet microsatellite loci and their cross-species utility in the ringnecked parakeet. These new microsatellites, when used in combination with the microsatellite markers previously published for use in these species [21, 22], will improve investigations into social and population genetic structure at a range of spatial scales, and help to examine the processes related to the invasion success of both species.

\section{Materials and methods}

\section{Sampling and DNA extraction}

Monk parakeet blood samples were collected in Barcelona, Spain (permit code: EPI 7/2015 (01529/1498/2015)) in May-July 2016 and 2017. Blood samples (maximum $100 \mu \mathrm{l}$ ) were taken from either the brachial or jugular vein of each individual, stored in $98 \%$ ethanol and kept at $-20{ }^{\circ} \mathrm{C}$ before DNA extraction.

DNA was extracted overnight using an ammonium acetate extraction protocol [23, 24]. DNA quality was assessed by gel electrophoresis and its concentration quantified using a fluorimeter (FLUOstar Optima, BMG LABTECH Ltd., Aylesbury, UK). The library was constructed using genomic DNA extracted from a single female monk parakeet sampled in Barcelona, Spain. Genomic DNA was digested with $\mathrm{MboI}$ and enriched for dinucleotide (AG, AC) and tetranucleotide (CTAA, CTTT, GATA, GTAA) repeat motifs; magnetic beads were used in the enrichment hybridisation (modified from $[25,26]$ ). An Illumina paired-end library was generated using $1 \mu \mathrm{g}$ of this repeat-enriched DNA. The NEBNext DNA Library Prep Kit for Illumina (New England Biolabs Inc.) protocol was followed and the DNA was sequenced using a MiSeq Benchtop Sequencer (Illumina Inc., San Diego, CA, USA). A total of 162 sequences that contained at least five tandem repeats were extracted from the data (EMBL-EBI accession numbers LR700312-LR700620). Twenty of these were selected and used to design primer sets.

\section{Primer design and microsatellite evaluation}

Primer pairs were designed using Primer3 v. 0.4.0 [27-29] in microsatellite flanking regions with a product size range from 100 to $270 \mathrm{bp}$. Further specifications for selecting primer pairs were: a melting temperature of $59-61{ }^{\circ} \mathrm{C}$ (optimum $60{ }^{\circ} \mathrm{C}$, difference $0.5{ }^{\circ} \mathrm{C}$ ), a length of 18 to 36 base pairs ( $20 \mathrm{bp}$ optimum) the presence of a G/C clamp, a maximum poly-X of 3 tandemly repeating nucleotides (e.g. TTT), and all other parameters set to default. Forward primers were 5 '-labelled with a fluorescent dye (HEX or 6-FAM). BLAST software [30] was used to assess and select unique sequences for primer design.

DNA from 24 monk parakeets ( 12 male and 12 female) was amplified using polymerase chain reaction (PCR) to assess microsatellite variability. Monk parakeets are sexually monomorphic [9], therefore genetic sex-typing was used to determine the sex of individuals and to enable the identification of sex-linked microsatellite loci. Of nine bird sexing markers tested in monk parakeets, five were successful: P2-P8 [31], P2D-P8 [32], Z002B [33], Z43B [34] and 2550F-2718 [35]. Two of these sex markers were used in the present study (P2-P8 [31] and Z002B [33]) to avoid any potential errors in sexing caused by misidentification of the $\mathrm{Z}$ and $\mathrm{W}$ alleles due to $\mathrm{Z} / \mathrm{W}$-polymorphism or the presence of heteroduplexes [36-38]. PCR amplification was performed using a DNA Engine Tetrad $®$ Thermal Cycler (MJ Research, Bio-Rad, Herts, UK) in $2 \mu$ reaction volumes containing 10-50 ng of air-dried DNA, $1 \mu \mathrm{l}$ QIAGEN Multiplex PCR mix (containing PCR buffer, HotStarTaq DNA polymerase, $1.5 \mathrm{mM} \mathrm{MgCl} 2$ and $0.2 \mu \mathrm{m}$ dNTPs; QIAGEN Inc.) and $0.2 \mu \mathrm{M}$ of each primer. Initial denaturation stage was carried out at $95{ }^{\circ} \mathrm{C}$ for $15 \mathrm{~min}$, followed by a PCR amplification of 35 cycles $\left(94{ }^{\circ} \mathrm{C}\right.$ for $30 \mathrm{~s}, 58{ }^{\circ} \mathrm{C}$ for $90 \mathrm{~s}$ and $72{ }^{\circ} \mathrm{C}$ for $60 \mathrm{~s}$ ) and a final extension for $30 \mathrm{~min}$ at $60^{\circ} \mathrm{C}$. Sex-typing markers P2-P8 and Z002B were amplified using annealing temperatures $50{ }^{\circ} \mathrm{C}$ and $56{ }^{\circ} \mathrm{C}$ respectively. $1 \mu \mathrm{l}$ of PCR product was diluted to a ratio of 1:2500-1:5000 (product: $\mathrm{H}_{2} \mathrm{O}$ ) and these products were then separated on an ABI 3730 48-capillary DNA Analyser using formamide and GeneScan ${ }^{\mathrm{TM}}-500$ ROX size-standard (Applied Biosystems, Warrington, UK). Alleles were scored using GENEMAPPER v 5 software (Applied Biosystems, California, USA). 


\section{Data analysis}

Allele numbers, polymorphic information content (PIC), estimated null allele frequencies, and observed $\left(\mathrm{H}_{\mathrm{o}}\right)$ and expected heterozygosities $\left(\mathrm{H}_{\mathrm{E}}\right)$ were calculated using CERVUS v3.0.7 [39]. Linkage disequilibrium and any departures from Hardy-Weinberg equilibrium were calculated using GENEPOP web version 4.2 [40]. In order to correct for multiple testing, a false discovery rate control (FDR) [41] was applied to $\mathrm{p}$-values obtained for linkage disequilibrium. MLRELATE was used to estimate maximum-likelihood coefficients of relatedness for each dyad [42], confirming that the individuals used to characterise the microsatellite loci were unrelated $(\mathrm{r}<0.19$, mean $\pm \mathrm{SD}=0.02 \pm 0.04)$.

\section{Cross-species utility}

Ring-necked parakeet blood samples were collected in November-March 2015-2017 in Barcelona, Spain (permit code: EPI 7/2015 (01529/1498/2015)). Blood samples (maximum $100 \mu \mathrm{l}$ ) were extracted from the jugular or brachial vein and stored at $-20{ }^{\circ} \mathrm{C}$ in $98 \%$ ethanol. An ammonium acetate extraction protocol was used for DNA extraction (see above for details), PCR amplification was conducted on DNA extracted from 18 ring-necked parakeets (11 females and 7 males; sexed using P2-P8 [31] and Z002B [33]), and microsatellite variability was then assessed as described for monk parakeets.

\section{Results and discussion}

\section{Microsatellite characterisation}

Of the 20 microsatellite loci tested, 17 successfully amplified and 16 were polymorphic in monk parakeets with allele numbers ranging from 2 to 14 with a mean of 8.06 alleles per locus (Table 1). $\mathrm{H}_{\mathrm{O}}$ and $\mathrm{H}_{\mathrm{E}}$ ranged from 0.23 to 0.96 and 0.43 to 0.93 , respectively. PIC values ranged from 0.33 to 0.90 with 15 of the 16 microsatellite loci being highly informative (PIC $>0.50$ ) and the other locus being reasonably informative $(0.50>$ PIC $>0.25$; following [43]). One locus, MmonZ12, was heterozygous in some males (ZZ) yet homozygous in all 12 females (ZW) indicating it is sex-linked (Z-linked; Fisher's exact test, $\mathrm{p}=0.004)$. All 15 other polymorphic loci amplified in both males and females, with no loci being homozygous in all females and all loci displaying heterozygotes in both males and females, and were therefore presumed to be located on the autosomes. For the Z-linked locus (MmonZ12), deviation from Hardy-Weinberg equilibrium was assessed in males only. Four loci (Mmon03, Mmon08, Mmon10 and Mmon13) exhibited significant deviations from Hardy-Weinberg equilibrium $(\mathrm{p}<0.05)$, which may suggest the presence of null alleles. However, only one locus (Mmon08) possessed a high estimated null allele frequency $(>10 \%)$. Alternatively, deviations from Hardy-Weinberg equilibrium may result from population structure [44]. Following FDR control, no significant linkage disequilibrium was found between loci. Multiplex Manager 1.2 [45] was used to generate a multiplex marker set from these 16 loci, optimised in three plexes; these multiplexes were then validated by genotyping the same 24 individual monk parakeets that had been genotyped in single-plex (Table 1).

\section{Cross-species utility}

Nine of the 20 microsatellite loci also amplified and were polymorphic in the ring-necked parakeet (Table 2). One of the nine loci polymorphic in ring-necked parakeets (Mmon17, Table 2) was monomorphic in monk parakeets and therefore was not included in the multiplex set for monk parakeets (Table 1). Allele numbers in ring-necked parakeets ranged from 2 to 10 (mean 5.22), $\mathrm{H}_{\mathrm{O}}$ and $\mathrm{H}_{\mathrm{E}}$ ranged from 0.12 to 0.89 and 0.11 to 0.89 , respectively, and PIC values ranged from 0.11 to 0.85 (Table 2), with five loci being highly informative (PIC $>0.50$ ), and one locus being reasonably informative $(0.50>\mathrm{PIC}>0.25$; [43]). MmonZ12 was also sex-linked in ring-necked parakeets (Fisher's exact test; $p<0.001$ ), as in monk parakeets, but was more variable in ring-necked parakeets displaying a total of 10 different alleles in 18 individuals (Table 2). $\mathrm{Z}$ chromosome polymorphism was observed for both sex markers (P2-P8 and Z002B) in two out of 18 ring-necked parakeets (allele sizes: P2-P8 Z alleles 369 and $375 \mathrm{bp}$, W allele $403 \mathrm{bp}$; Z002B Z alleles 250 and $252 \mathrm{bp}$, W allele $234 \mathrm{bp}$ ) and was accounted for when assigning sex. Four loci (Mmon01, Mmon05, Mmon15 and MmonZ12) deviated significantly from Hardy-Weinberg equilibrium $(\mathrm{p}<0.05)$ and two loci (Mmon03 and Mmon15) possessed a high estimated null allele frequency $(>10 \%)$ in ringnecked parakeets. Linkage disequilibrium was significant between three pairs of alleles $(\mathrm{p}<0.05$; Mmon03 and Mmon04, Mmon04 and Mmon15, Mmon05 and Mmon15). However, this may be due to the presence of relatives in the sample of ring-necked parakeets used to characterise these microsatellite loci. ML-Relate [42] indicated the presence of possible half-sibling (19/153) and full-sibling relationships (6/153) and one potential parent-offspring relationship among the 18 ring-necked parakeets sampled. 
Table 1 Characterisation of novel monk parakeet (Myiopsitta monachus) microsatellite loci (Psittacidae, Aves)

\begin{tabular}{|c|c|c|c|c|c|c|c|c|c|}
\hline $\begin{array}{l}\text { Locus, } \\
\text { Accession no. }\end{array}$ & $\begin{array}{l}\text { Primer sequences } \\
\left(5^{\prime}-3^{\prime}\right) \text {; forward }(\mathrm{F}) \text {; } \\
\text { reverse }(\mathrm{R})\end{array}$ & Repeat motif & Multiplex & $\begin{array}{l}\text { Observed allele } \\
\text { size range (bp) }\end{array}$ & $\mathrm{n}$ & No. of alleles & $\mathrm{H}_{\mathrm{O}} / \mathrm{H}_{\mathrm{E}}$ & Est. null allele freq & PIC \\
\hline $\begin{array}{l}\text { Mmon01 } \\
\text { LR700312 }\end{array}$ & $\begin{array}{l}\text { F: [HEX] CCCACA } \\
\text { TGCTATGGT } \\
\text { CCAG } \\
\text { R: CTTCCAAGG } \\
\text { ATGAGGCAGAG }\end{array}$ & $(\text { TTAG })_{9}$ & 3 & $177-201$ & 23 & 7 & $0.70 / 0.72$ & 0.001 & 0.67 \\
\hline $\begin{array}{l}\text { Mmon02 } \\
\text { LR700313 }\end{array}$ & $\begin{array}{l}\text { F: [6-FAM] AATCTC } \\
\text { TAAAGAGGTCCA } \\
\text { CACTGC } \\
\text { R: TGGATGTCT } \\
\text { GAGGTGAACTCC }\end{array}$ & $(\mathrm{AC})_{16}$ & 1 & $141-173$ & 24 & 10 & $0.96 / 0.89$ & -0.05 & 0.85 \\
\hline $\begin{array}{l}\text { Mmon03 } \\
\text { LR700314 }\end{array}$ & $\begin{array}{l}\text { F: [6-FAM] TTTGCA } \\
\text { GTGACCTTCATT } \\
\text { CTG } \\
\text { R: CTACAGCCA } \\
\text { GCCTACTGTGC }\end{array}$ & $(\mathrm{TG})_{18}$ & 1 & $227-268$ & 24 & 11 & $0.71 / 0.86^{* *}$ & 0.09 & 0.83 \\
\hline $\begin{array}{l}\text { Mmon04 } \\
\text { LR700315 }\end{array}$ & $\begin{array}{l}\text { F: [HEX] ATCCTG } \\
\text { CCTGTGAACTCT } \\
\text { GG } \\
\text { R: CCTCCCTCACCA } \\
\text { TTCCAAG }\end{array}$ & $(\mathrm{GT})_{20}$ & 1 & $220-243$ & 24 & 10 & $0.75 / 0.85$ & 0.06 & 0.81 \\
\hline $\begin{array}{l}\text { Mmon05 } \\
\text { LR700316 }\end{array}$ & $\begin{array}{l}\text { F: [HEX] TCCTGT } \\
\text { CAAGGTGATGCT } \\
\text { TG } \\
\text { R: CTGTAGAAG } \\
\text { ATGGGAGGTTAG } \\
\text { AGTG }\end{array}$ & $(\mathrm{CTAT})_{18}$ & 1 & $166-202$ & 24 & 11 & $0.67 / 0.80$ & 0.09 & 0.76 \\
\hline $\begin{array}{l}\text { Mmon06 } \\
\text { LR700317 }\end{array}$ & $\begin{array}{l}\text { F: [HEX] GGGAAT } \\
\text { TCAGTGGAAAGA } \\
\text { GG } \\
\text { R: CCCAAATCA } \\
\text { GATTCTTGCTTC }\end{array}$ & $(\mathrm{CA})_{17}$ & 2 & $191-219$ & 24 & 10 & $0.83 / 0.84$ & -0.002 & 0.80 \\
\hline $\begin{array}{l}\text { Mmon07 } \\
\text { LR700318 }\end{array}$ & $\begin{array}{l}\text { F: [6-FAM] TGGCAG } \\
\text { TATGAAACATAC } \\
\text { ACACAG } \\
\text { R: GGAAGCCAC } \\
\text { CAAGATTTCAG }\end{array}$ & $(\mathrm{ATCT})_{16}$ & 2 & $197-229$ & 24 & 14 & $0.88 / 0.93$ & 0.02 & 0.90 \\
\hline $\begin{array}{l}\text { Mmon08 } \\
\text { LR700319 }\end{array}$ & $\begin{array}{l}\text { F: [6-FAM] AAA } \\
\text { CCCAATGGCAGT } \\
\text { GTTTC } \\
\text { R: ACCATGGAG } \\
\text { CTGAGGAACAG }\end{array}$ & $(\text { TGGA })_{7}$ & 3 & $240-250$ & 22 & 4 & $0.23 / 0.61 * *$ & $0.44 * * *$ & 0.54 \\
\hline $\begin{array}{l}\text { Mmon09 } \\
\text { LR700320 }\end{array}$ & $\begin{array}{l}\text { F: [HEX] ATCCAC } \\
\text { AATCGTCAGATG } \\
\text { GAG } \\
\text { R: AAATGGGAA } \\
\text { GTGAACCCAGAG }\end{array}$ & $(\mathrm{AC})_{13}$ & 3 & $136-148$ & 24 & 6 & $0.71 / 0.70$ & -0.01 & 0.64 \\
\hline $\begin{array}{l}\text { Mmon10 } \\
\text { LR700321 }\end{array}$ & $\begin{array}{l}\text { F: [6-FAM] TCAGTC } \\
\text { AAGATGTTCCCT } \\
\text { TGG } \\
\text { R: GAGACAACA } \\
\text { GCTCATCTTCCT } \\
\text { CTAC }\end{array}$ & $(\mathrm{TG})_{14}$ & 3 & 90-101 & 24 & 7 & $0.75 / 0.81 * *$ & 0.03 & 0.77 \\
\hline $\begin{array}{l}\text { Mmon11 } \\
\text { LR700322 }\end{array}$ & $\begin{array}{l}\text { F: [6-FAM] TGCAGT } \\
\text { AATGATTTGATG } \\
\text { CATTG } \\
\text { R: ACAAGCACA } \\
\text { CCTCGCAAAC }\end{array}$ & $(\text { TATC })_{11}$ & 3 & $153-173$ & 24 & 6 & $0.71 / 0.72$ & 0.01 & 0.67 \\
\hline
\end{tabular}


Table 1 (continued)

\begin{tabular}{|c|c|c|c|c|c|c|c|c|c|}
\hline $\begin{array}{l}\text { Locus, } \\
\text { Accession no. }\end{array}$ & $\begin{array}{l}\text { Primer sequences } \\
\left(5^{\prime}-3^{\prime}\right) \text {; forward }(\mathrm{F}) \text {; } \\
\text { reverse }(\mathrm{R})\end{array}$ & Repeat motif & Multiplex & $\begin{array}{l}\text { Observed allele } \\
\text { size range (bp) }\end{array}$ & $\mathrm{n}$ & No. of alleles & $\mathrm{H}_{\mathrm{O}} / \mathrm{H}_{\mathrm{E}}$ & Est. null allele freq & PIC \\
\hline \multirow[t]{2}{*}{$\begin{array}{l}\text { MmonZ12 } \\
\text { LR700323 }\end{array}$} & $\begin{array}{l}\text { F: [6-FAM] GCTTTC } \\
\text { TCTGTGAAATCC } \\
\text { ATCC } \\
\text { R: AACATCATC } \\
\text { TTAAGAACCATC } \\
\text { CAAG }\end{array}$ & $(\mathrm{ATCT})_{6}$ & 1 & $103-107$ & $12 \mathrm{M}$ & 2 & $0.58 / 0.43$ & -0.17 & 0.33 \\
\hline & & & 1 & $103-107$ & $12 \mathrm{~F}$ & 2 & $0 / 0$ & NA & NA \\
\hline $\begin{array}{l}\text { Mmon13 } \\
\text { LR700324 }\end{array}$ & $\begin{array}{l}\text { F: [6-FAM] CAGTAT } \\
\text { ACCTATGGTTAA } \\
\text { GGTTTCAGC } \\
\text { R: CCTTGATTCAGA } \\
\text { TGGTAATTAGAG } \\
\text { AAG }\end{array}$ & $(\text { TCTA })_{14}$ & 3 & $122-144$ & 24 & 6 & $0.88 / 0.79 * *$ & -0.07 & 0.74 \\
\hline $\begin{array}{l}\text { Mmon14 } \\
\text { LR700325 }\end{array}$ & $\begin{array}{l}\text { F: [HEX] CTTTCT } \\
\text { AACTCATTCCTA } \\
\text { AGTGAGAGC } \\
\text { R: GACTCTGTC } \\
\text { TGACTCCTATTG } \\
\text { CTG }\end{array}$ & $(\mathrm{GT})_{16}$ & 1 & $142-164$ & 24 & 9 & $0.83 / 0.82$ & -0.02 & 0.77 \\
\hline $\begin{array}{l}\text { Mmon15 } \\
\text { LR700326 }\end{array}$ & $\begin{array}{c}\text { F: [HEX] TTAAAC } \\
\text { AACAGTATTTGT } \\
\text { GAGACCAAG } \\
\text { R: TCCTTTCCAACC } \\
\text { CTAACTATTCTG }\end{array}$ & $(\mathrm{AGAT})_{14}$ & 2 & $130-176$ & 24 & 11 & $0.83 / 0.88$ & 0.02 & 0.85 \\
\hline $\begin{array}{l}\text { Mmon16 } \\
\text { LR700327 }\end{array}$ & $\begin{array}{l}\text { F: [6-FAM] CAA } \\
\text { ACAGTCTTCCCT } \\
\text { TTGTGG } \\
\text { R: AAACACAGG } \\
\text { CCCATCTGC }\end{array}$ & $(\mathrm{AC})_{12}$ & 2 & $141-167$ & 24 & 5 & $0.67 / 0.65$ & -0.03 & 0.57 \\
\hline $\begin{array}{l}\text { Mmon17* } \\
\text { LR700328 }\end{array}$ & $\begin{array}{l}\text { F: [HEX] AGGTCC } \\
\text { TTTACAGCCCTA } \\
\text { ACTG } \\
\text { R: GTTGAACTT } \\
\text { CCCAGCTTTCC }\end{array}$ & $(\mathrm{TG})_{26}$ & NA & 254 & 22 & 1 & NA & NA & NA \\
\hline
\end{tabular}

EMBL-EBI sequence accession numbers LR700312-LR700328, number of individuals results are based on (n), observed and expected heterozygosities (HO and HE respectively)

**Loci with significant departures from Hardy-Weinberg equilibrium; estimated null allele frequency (Est. null allele freq.)

$* * *$ Mmon08 possessed high estimated null allele frequency ( $>10 \%)$, not applicable (NA); polymorphic information content (PIC)

Mmon17* was monomorphic in monk parakeets and not included in the multiplex set

\section{Limitations}

DNA samples from monk parakeets and ring-necked parakeets used to characterise these microsatellite loci were taken from invasive populations for which there is no detailed knowledge of introduction events. Therefore, it is possible that these individuals are descendants from small founding populations which may have had limited genetic variation. On the other hand, both species have very extensive native ranges across South America (monk parakeet) and Africa and Asia (ring-necked parakeet) [9] and if founders were drawn from across these ranges, genetic variation of invasive populations may be greater than in local populations within their native range. 
Table 2 Cross-species utility of monk parakeet (Myiopsitta monachus) microsatellite loci in the ring-necked parakeet (Psittacula krameri)

\begin{tabular}{lccllll}
\hline Locus & $\mathrm{n}$ & No. of alleles & $\begin{array}{l}\text { Observed allele } \\
\text { size range }(\mathrm{bp})\end{array}$ & $\mathrm{H}_{\mathrm{O}} / \mathrm{H}_{\mathrm{E}}$ & Est. null allele freq. & PIC \\
\hline Mmon01 & 17 & 6 & $165-193$ & $0.71 / 0.78^{* *}$ & 0.003 & 0.72 \\
Mmon03 & 18 & 2 & $216-218$ & $0.22 / 0.29$ & $0.11^{* * *}$ & 0.24 \\
Mmon04 & 18 & 3 & $204-207$ & $0.39 / 0.48$ & 0.07 & 0.41 \\
Mmon05 & 18 & 10 & $127-176$ & $0.83 / 0.89 * *$ & 0.02 & 0.85 \\
Mmon07 & 18 & 8 & $189-217$ & $0.89 / 0.84$ & -0.04 & 0.79 \\
Mmon09 & 17 & 3 & $142-148$ & $0.18 / 0.17$ & -0.04 & 0.16 \\
MmonZ12 & $7 \mathrm{M}$ & $7 *$ & $201-245$ & $1.00 / 0.88^{* *}$ & 0 & 0.79 \\
& $11 \mathrm{~F}$ & $8^{*}$ & $205-245$ & $0 / 0$ & $\mathrm{NA}$ & $\mathrm{NA}$ \\
Mmon15 & 17 & 6 & $138-155$ & $0.35 / 0.80^{* *}$ & $0.38^{* * *}$ & 0.74 \\
Mmon17 & 17 & 2 & $218-226$ & $0.12 / 0.11$ & -0.02 & 0.11 \\
\hline
\end{tabular}

Tested in 18 ring-necked parakeets; number of individuals results are based on (n)

*A total of ten different alleles were observed for MmonZ12, observed and expected heterozygosities $\left(\mathrm{H}_{\mathrm{O}}\right.$ and $\mathrm{H}_{\mathrm{E}}$ respectively)

**Loci with significant departures from Hardy-Weinberg equilibrium; estimated null allele frequency (Est. null allele freq.)

***Mmon03 and Mmon15 possessed high null allele frequencies (>10\%), not applicable (NA); polymorphic information content (PIC)

\section{Conclusions}

These novel microsatellite loci, optimised in three multiplexes, provide a powerful tool for analyses of both fine and broad-scale population genetic structure, as well as for analyses of parentage and dyadic relatedness. Combining these markers with those previously published for use in both monk parakeets [21] and ring-necked parakeets [22] will facilitate detailed investigations into behavioural and population processes related to invasion success in these two widespread avian invaders. Such studies are likely to be particularly interesting in the case of monk parakeets given that they are highly social parrots, with unique compound nests made of sticks that may house many breeding pairs, often built in close proximity to other nests to form loose colonies $[9,46]$. Furthermore, examination of population genetic structure at a range of spatial scales may aid in the design of effective management strategies, help to understand the history of invasive populations and to predict future range expansions in these species.

Acknowledgements MiSeq sequencing was performed by Dr Rebecca Thomas at the Sheffield Diagnostics Genetics Service at The Children's Hospital Sheffield supported by the Sheffield Children's NHS Trust, UK. Dr Natalie dos Remedios provided training in the lab techniques.

Author contributions BJH, JCS and FSEDP designed the study. JCS supervised the field study and JCS and AOS collected the blood samples. BJH and JCS supervised the project. FSEDP and GJH conducted laboratory work at the NERC Biomolecular Analysis Facility, Sheffield, UK. FSEDP and DAD analysed the data. FSEDP wrote the paper with input from co-authors. All authors read and approved the final manuscript.

Funding The study was funded by a UK Natural Environment Research Council (NERC) Biomolecular Analysis Facility (NBAF) grant (NBAF1078) to BJH, JCS and Daniel Franks (University of York) for laboratory work conducted at the University of Sheffield, UK, and by a NERC studentship to FSEDP through the ACCE Doctoral Training Partnership at the University of Sheffield, UK. Sample collection was funded by a grant (CGL-2016-79568-C3-3-P) to JCS from the Spanish Research council (Ministry of Economics and Enterprise).

Data availability The microsatellite sequences are available through EMBL-EBI and are accessible via the Accession Numbers: LR700312-LR700328.

\section{Compliance with ethical standards}

Conflict of interest The authors declare they have no conflict of interest.

Ethical approval Birds were handled and blood samples taken with special permission EPI 7/2015 (01529/1498/2015) from Direcció General del Medi Natural i Biodiversitat, Generalitat de Catalunya, following Catalan regional ethical guidelines for the handling of birds. JCS received special authorization (001501-0402.2009) for the handling of animals in research from Servei de Protecció de la Fauna, Flora i Animal de Companyia, according to Decree 214/1997/30.07, Generalitat de Catalunya. 
Informed consent All authors consent to publication.

Open Access This article is licensed under a Creative Commons Attribution 4.0 International License, which permits use, sharing, adaptation, distribution and reproduction in any medium or format, as long as you give appropriate credit to the original author(s) and the source, provide a link to the Creative Commons licence, and indicate if changes were made. The images or other third party material in this article are included in the article's Creative Commons licence, unless indicated otherwise in a credit line to the material. If material is not included in the article's Creative Commons licence and your intended use is not permitted by statutory regulation or exceeds the permitted use, you will need to obtain permission directly from the copyright holder. To view a copy of this licence, visit http://creativecommons.org/licenses/by/4.0/.

\section{References}

1. Kolar CS, Lodge DM (2001) Progress in invasion biology: predicting invaders. Trends Ecol Evol 16:199-204

2. Duncan RP, Blackburn TM, Sol D (2003) The ecology of bird introductions. Annu Rev Ecol Evol Syst 34:71-98

3. Kumschick S, Nentwig W (2010) Some alien birds have as severe an impact as the most effectual alien mammals in Europe. Biol Conserv 143:2757-2762

4. Pimentel D (2002) Biological invasions: economic and environmental costs of alien plant, animal, and microbe species. CRC Press, Florida

5. Bax N, Williamson A, Aguero M, Gonzalez E, Geeves W (2003) Marine invasive alien species: a threat to global biodiversity. Mar Policy 27:313-323

6. Clavero M, Garcia-Berthou E (2005) Invasive species are a leading cause of animal extinctions. Trends Ecol Evol 20:110

7. Juliano SA, Lounibos LP (2005) Ecology of invasive mosquitoes: effects on resident species and on human health. Ecol Lett 8:558-574

8. Pyšek P, Richardson DM (2010) Invasive species, environmental change and management, and health. Annu Rev Environ Resour $35: 25-55$

9. Forshaw JM (1989) Parrots of the world, 3rd edn. David and Charles, London

10. Russello MA, Avery ML, Wright TF (2008) Genetic evidence links invasive monk parakeet populations in the United States to the international pet trade. BMC Evol Biol 8:217

11. CITES: Trade Database. Myiopsitta monachus. https://trade .cites.org. Accessed 30 Jul 2019

12. Senar JC, Domènech J, Arroyo L, Torre I, Gordo O (2016) An evaluation of monk parakeet damage to crops in the metropolitan area of Barcelona. Anim Biodivers Conserv 39:141-145

13. Newman JR, Newman CM, Lindsay JR, Merchant B, Avery ML, Pruett-Jones S (2008) Monk parakeets: an expanding problem on power lines and other electrical utility structures. In: Environment concerns rights-of-way management 8th international symposium, pp 355-363

14. Butler CJ (2003) Population Biology of the Introduced Roseringed Parakeet Psittacula krameri in the UK. PhD Thesis, Department of Zoology Edward Grey Institute of Field Ornithology, Oxford, UK

15. Lever C (2005) Naturalised birds of the world. T \& A.D. Poyser, London
16. Strubbe D, Matthysen E (2009) Experimental evidence for nestsite competition between invasive ring-necked parakeets (Psittacula krameri) and native nuthatches (Sitta europaea). Biol Conserv 142:1588-1594

17. Hernández-Brito D, Carrete M, Ibáñez C, Juste J, Tella JL (2018) Nest-site competition and killing by invasive parakeets cause the decline of a threatened bat population. R Soc Open Sci 5:172477

18. Prentis PJ, Sigg DP, Raghu S, Dhileepan K, Pavasovic A, Lowe AJ (2009) Understanding invasion history: genetic structure and diversity of two globally invasive plants and implications for their management. Divers Distrib 15:822-830

19. LaRue EA, Ruetz CR, Stacey MB, Thum RA (2011) Population genetic structure of the round goby in Lake Michigan: implications for dispersal of invasive species. Hydrobiologia 663:71-82

20. Abdelkrim J, Pascal M, Calmet C, Samadi S (2005) Importance of assessing population genetic structure before eradication of invasive species: examples from insular Norway rat populations. Conserv Biol 19:1509-1518

21. Russello MA, Saranathan V, Buhrman-Deever S, Eberhard J, Caccone A (2007) Characterization of polymorphic microsatellite loci for the invasive monk parakeet (Myiopsitta monachus). Mol Ecol Notes 7:990-992

22. Raisin C, Dawson DA, Greenwood AG, Jones CG, Groombridge JJ (2009) Characterization of Mauritius parakeet (Psittacula eques) microsatellite loci and their cross-utility in other parrots (Psittacidae, Aves). Mol Ecol Resour 9:1231-1235

23. Nicholls JA, Double MC, Rowell DM, Magrath RD (2000) The evolution of cooperative and pair breeding in thornbills Acanthiza (Pardalotidae). J Avian Biol 31:165-176

24. Richardson DS, Jury FL, Blaakmeer K, Komdeur J, Burke $T$ (2001) Parentage assignment and extra-group paternity in a cooperative breeder: the Seychelles warbler (Acrocephalus sechellensis). Mol Ecol 10:2263-2273

25. Armour JAL, Neumann R, Gobert S, Jeffreys AJ (1994) Isolation of human simple repeat loci by hybridization selection. Hum Mol Genet 3:599-605

26. Glenn TC, Schable NA (2005) Isolating microsatellite DNA loci. In: Zimmer EA, Roalson EH (eds) Methods in enzymology, vol 395. Academic Press, San Diego, pp 202-222

27. Rozen S, Skaletsky H (2000) Primer3 on the WWW for general users and for biologist programmers. In: Misener S, Krawetz SA (eds) Bioinformatics methods and protocols. Humana Press, Totowa, pp 365-386

28. Koressaar T, Remm M (2007) Enhancements and modifications of primer design program Primer3. Bioinformatics 23:1289-1291

29. Untergasser A, Cutcutache I, Koressaar T, Ye J, Faircloth BC, Remm M, Rozen SG (2012) Primer3-new capabilities and interfaces. Nucleic Acids Res 40:e115

30. Altschul SF, Madden TL, Schäffer AA, Zhang J, Zhang Z, Miller W, Lipman DJ (1997) Gapped BLAST and PSI-BLAST: a new generation of protein database search programs. Nucleic Acids Res 25:3389-3402

31. Griffiths R, Double MC, Orr K, Dawson RJG (1998) A DNA test to sex most birds. Mol Ecol 7:1071-1075

32. Dawson DA, Horsburgh GJ, Krupa AP, Stewart IRK, Skjelseth S, Jensen H, Ball AD, Spurgin LG, Mannarelli M-E, Nakagawa S, Schroeder S, Vangestel C, Hinten GN, Burke T (2012) Microsatellite resources for Passeridae species: a predicted microsatellite map of the house sparrow Passer domesticus. Mol Ecol Resour 12:501-523 
33. Dawson DA (2007) Genomic analysis of passerine birds using conserved microsatellite loci. PhD Thesis, University of Sheffield, UK

34. Dawson DA, dos Remedios N, Horsburgh GJ (2016) A new marker based on the avian spindlin gene that is able to sex most birds, including species problematic to sex with CHD markers. Zoo Biol 35:533-545

35. Fridolfsson AK, Ellegren H (1999) A simple and universal method for molecular sexing of non-ratite birds. J Avian Biol 30:116-121

36. Dawson DA, Darby S, Hunter FM, Krupa AP, Jones IL, Burke $T$ (2001) A critique of avian CHD-based molecular sexing protocols illustrated by a Z-chromosome polymorphism detected in auklets. Mol Ecol Notes 1:201-204

37. Robertson BC, Gemmell NJ (2006) PCR-based sexing in conservation biology: wrong answers from an accurate methodology? Conserv Genet 7:267-271

38. Casey AE, Jones KL, Sandercock BK, Wisely SM (2009) Heteroduplex molecules cause sexing errors in a standard molecular protocol for avian sexing. Mol Ecol Resour 9:61-65

39. Kalinowski ST, Taper ML, Marshall TC (2007) Revising how the computer program CERVUS accommodates genotyping error increases success in paternity assignment. Mol Ecol 16:1099-110640

40. Rousset F (2008) GENEPOP'007: a complete re-implementation of the GENEPOP software for Windows and Linux. Mol Ecol Resour 8:103-106
41. Verhoeven KJ, Simonsen KL, McIntyre LM (2005) Implementing false discovery rate control: increasing your power. Oikos 108:643-647

42. Kalinowski ST, Wagner AP, Taper ML (2006) ML-relate: a computer program for maximum likelihood estimation of relatedness and relationship. Mol Ecol Notes 6:576-579

43. Botstein D, White RL, Skolnick M, Davis RW (1980) Construction of a genetic linkage map in man using restriction fragment length polymorphisms. Am J Hum Genet 32:314-331

44. Waples RS (2014) Testing for Hardy-Weinberg proportions: have we lost the plot? J Hered 106:1-19

45. Holleley CE, Geerts PG (2009) Multiplex Manager 1.0: a crossplatform computer program that plans and optimizes multiplex PCR. Biotechniques 46:511-517

46. Bucher EH, Martin LF, Martella MB, Navarro JL (1990) Social behaviour and population dynamics of the Monk Parakeet. Proc Int Ornithol Congr 20:681-689

Publisher's Note Springer Nature remains neutral with regard to jurisdictional claims in published maps and institutional affiliations. 